\title{
Economics and Importance of Beekeeping
}

\author{
Veer Sain* and Jitender Nain \\ Department of Agricultural Economics, Haryana Agricultural University, India
}

Received: November 16, 2017; Published: December 04, 2017

*Corresponding author: Veer Sain, Department of Agricultural Economics, Department of Agricultural Economics, Haryana Agricultural University, Hisar 123005, India; Email: 3veersain@gmail.com

\section{Opinion}

Apiculture or Beekeeping is the art and science of collecting, processing honeybee colonies of desired species having them in specified and standard boxes, installing at appropriate sites, managing optimum number of colonies scientifically round the year and harnessing both direct and indirect benefits of the activities. As such a degree or high qualification is not essential in order to work in this profession. Apiarists can be developed and trained to handle the enterprise. There is vast potential and scope from diversification in Apiculture i.e. besides honey its offers scope for production and marketing of other bee products like bee pollen, bee propels, bee way bee venom and Royal selling. Honeybees can also be managed as and when required for pollination of field and Horticultural crops and for hybrid seed production in vegetables and other bee pollination crops technologies for the production of different products i.e. Royal jelly, bee pollen, bee porpoise, bee venom, Queen bees, package bees etc. now available in India Thakur 2008.

Table 1: Economics of Beekeeping.

\begin{tabular}{|c|c|c|}
\hline Sr. No. & Details of items & Amount in Rs $/-$ \\
\hline 1 & Cost of 10 number of beehives per box & $2000 \times 80=1,60,000$ \\
\hline 2 & Cost of 80 bee box & $80 \times 400=32,000$ \\
\hline 3 & Cost of Apiery equipments & 8,000 \\
\hline 4 & Cost of honey unit and uncapping tray & 15.500 \\
\hline 5 & Bee wax sheet $1 \mathrm{~kg}$ & 400 \\
\hline
\end{tabular}

In Haryana state, commercial beekeepers are keeping Apis mellifera $L$. bee whose queen is highly prolific and lay about 1500-2000 eggs per day during honey flow season. Therefore the colonies always remain in good strength. At present Haryana state is one of the leading state in India in honey production in the year 2004-05 there were only 28,000 colonies from which about $275 \mathrm{mt}$ of honey (years 2015-16) about 3,05,000 bee colonies from which about $4100 \mathrm{mt}$ honey in produced annually. Haryana has vast resources of bee flora, there is a great scope for further expansion of beekeeping in the state. In Haryana, where land holding is less than 0.75 ha beekeeping can provide better food, balanced nutrition and employment to small and marginal farmers. It can also provide the unemployed and underemployed persons with full employment and extra income. A honey bee is member of the genus Apis, primarily distinguished by the production and storage of honey and the construction of perennial, colonial nests from wax Table 1.

Currently only 7 species of honeybee are recognized the best known honey bee species Apis mellifera L. (western honey bee) which has domesticated for honey production and crop pollination. Honey bees present only a small fraction of roughly 20,000 known species of bees. But only members of the genial Apis are true honey bees. Two species of honey bee Apis mellifera L. and Apis cerana indica F. (Indian Honey bee) are often maintained fed and transported by beekeepers. Modern bee hives also enable beekeepers to transport bees, moving from field to field as the crop needs pollinating and allowing the beekeeper to charge for the pollination services. They provide, revising the historical role of the self employed beekeeper and favoring large scale commercial operations Table 2.

Table 2: Economics of Honey production and returns.

\begin{tabular}{|c|c|c|}
\hline Sr. No. & Details of items & Amount in Rs. \\
\hline 1 & Honey production 80 Rs. $\times 40 \mathrm{~kg}$ & $3200 \mathrm{Rs} / \mathrm{Box}$ \\
\hline 2 & For 80 boxes $=80 \times 3200$ & $2,56,000$ \\
\hline 3 & Labour $($ skilled) cost $5000 \times 12$ & 60,000 \\
\hline 4 & Unskilled labour cost $3500 \times 12$ & 42,000 \\
\hline 5 & Migration charges & 20,000 \\
\hline 6 & Feed charges annual & 10,000 \\
\hline 7 & Total & $1,32,000 * 1$ \\
\hline 8 & New 25 box $\times 700$ each & 17,500 \\
\hline 9 & Net profit & $1,49,500^{* 2}$ \\
\hline
\end{tabular}

\section{Bee Keeping Industry}

Beekeeping is an ideal activity which provides supplementary income to a large number of rural, hilly and tribal production and also for horticulturists, agriculturists, hobbyist etc. because of the rich flora available in abundance in the country. Any beginner who wants to start beekeeping should known some of the aspects of beehives, tools, locations where honey bees can be kept with its 
attempt to known honey bee and its start with one should known and learn more about honey bee and its requirement in order to make honey bee work for beekeeper. Most valuable return of the industry is the honey, wax and pollination service rendered by bees which increase yield of many of the agricultural and horticultural crops.

${ }^{* 1}$ Total of $60,000+42,000+20,000+10,000=1,32,000$
${ }^{* 2}$ Total of $1,32,000+17,500=1,49,500$

Return expenses $=$ Honey production-Net profit $272000-149500=1,22,500$ Rs/-

Bee's increase $(25 \times 1800)=45,000$ Rs $/-$

Net profit annual =1, 67,500 Rs. Which is excellent profit?

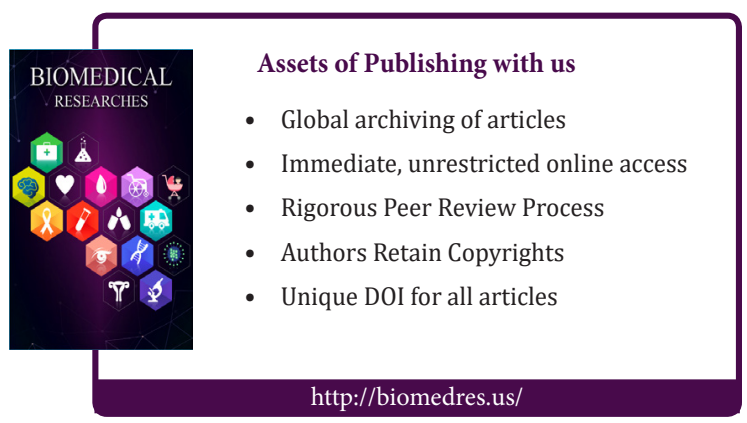

